\title{
Effects of moisture and cellulose fibril angle on the tensile properties of native single Norway spruce wood fibres
}

\author{
Nils Horbelt ${ }^{1} \cdot$ John W. C. Dunlop ${ }^{2}$. Luca Bertinetti ${ }^{1,3} \cdot$ Peter Fratzl $^{1}$. \\ Michaela Eder ${ }^{1} \mathbb{D}$
}

Received: 3 March 2021 / Accepted: 17 June 2021 / Published online: 5 July 2021

(c) The Author(s) 2021

\begin{abstract}
Isolated single wood fibres with cellulose fibril angles from 10 to $43^{\circ}$ were tested in microtensile tests under controlled temperature and relative humidity of $5,50,75$, $90 \%$ and in the wet state. This systematic study provides experimental stiffness and strength data, calculated on cell wall cross sections. It has been shown that stiffness reduction with increasing moisture content is more pronounced in fibres with large cellulose fibril angles. Interestingly, stiffness reduction in fibres with low cellulose fibril angles has been observed for the fully hydrated state only. The experimental dataset was fed into a model to determine moisture dependent stiffness of the hemicellulose-lignin-matrix and the stresses acting on the fibrils and the matrix.
\end{abstract}

\section{Introduction}

Wood in a living tree is a structural material used for water and nutrient transport and mechanical stability. In terms of mechanics, flexibility is advantageous for stems and branches of young trees in order to cope with loads, such as those caused by wind, snow or animals. As the tree increases its size by growth, the stem needs to get stiffer to sufficiently support the crown. Density and the cellulose fibril angle are known to be the main parameters that control wood mechanical properties according to the needs of trees. However, like many other biological materials, wood also is hygroscopic and as such its material properties change with moisture content. This does not play a role for the fully hydrated living tree, but limits the use of wood

Michaela Eder

michaela.eder@mpikg.mpg.de

1 Department of Biomaterials, Max-Planck-Institute of Colloids and Interfaces, Am Mühlenberg

1, 14476 Potsdam, Germany

2 Morphophysics Group, Department of the Chemistry and Physics of Materials, Paris-Lodron-University of Salzburg, Salzburg, Austria

3 B CUBE-Center for Molecular Bioengineering, Technische Universität Dresden, 01307 Dresden, Germany 
for applications. Generally speaking, the strength and Young's modulus of wood decrease with increasing moisture content and wood becomes more susceptible to biodegradation. Furthermore, varying moisture contents lead to pronounced directional swelling and shrinkage, which is unfavourable for many applications. A prominent example from every day experience is the difficulty in opening and closing wooden doors and windows due to swelling or shrinking from changes in humidity. Apart from "negative" examples, the dependence of mechanical properties and swelling on moisture also provides potential for future applications, such as hygrosensitive actuators (Reyssat and Mahadevan 2009; Zhang et al. 2016), and humidity driven movements of shading elements or support for solar panels (Rüggeberg and Burgert 2015; Vailati et al. 2017).

The origin of these movements and the changing mechanical properties is to be found in the structure of the cell wall. The cell wall consists of dimensionally stable and very stiff ( $130 \mathrm{GPa}$, wet and dry) cellulose fibrils, embedded in a softer matrix of hemicelluloses (2 GPa dry, $20 \mathrm{MPa}$ wet) and lignin (2 GPa wet and dry) (Salmen 2004). Pronounced swelling upon water uptake occurs transversally to the longitudinal axis of the cellulose fibrils (Barnett and Bonham 2004). Since the stiffness and strength of the matrix polymers are much lower than those of cellulose, the cell wall strength and stiffness in the direction transverse to the fibrils are also lower and decrease even more upon hydration. Theoretical models have addressed these questions (Joffre et al. 2014; Pan and Zhong 2016), supported by experimental observations on both macro- and microscopic samples (Almeras et al. 2017; Kersevage 1973). The experimental determination of cell wall mechanical properties however is difficult, tedious, and faces limitations which are strongly dependent on the chosen method (Eder et al. 2013). Nanoindentation is one common method to probe cell wall properties (Eder et al. 2013; Gindl et al. 2004; Tze et al. 2007) and provides information about hardness and the indentation modulus, which depends on the longitudinal but also on the transverse and shear moduli (Gindl and Schoberl 2004; Jäger et al. 2011). Another method to assess cell wall mechanics on the microscale are single-fibre tensile tests. The resultant stress strain curves provide information about tensile stiffness which depends just on the longitudinal modulus, ultimate tensile stress and deformation and fracture behaviour and is strongly dependent on the microfibril angle (Burgert et al. 2002; Eder et al. 2013; Groom et al. 2002a, b; Keckes et al. 2003). The main aim of this study is to experimentally determine the relationship between cellulose fibril angle and mechanical properties at different moisture contents in the native wood cell wall by using single-fibre tensile tests. The applied experimental setup allows for the control of humidity and temperature during the test without any sample modification. Previous tensile tests on single wood fibres show that the decrease in fibre tensile stiffness with increasing moisture content is more pronounced for cell walls with higher MFAs such as juvenile wood and compression wood compared to cell walls with low MFAs such as those from adult wood (Eder et al. 2013). A limitation of this data is that it was obtained from various species and included different isolation and testing methods. Furthermore, the range of data available for different MFAs and relative humidities is limited. In this study, the aim is to address these limitations by systematically investigating the combined influence of microfibril angle and moisture content on the tensile stiffness of native 
spruce wood cells. The aim is to provide basic experimental data of single wood fibres that can be used at a later stage to better understand and predict the properties of wood and other plant tissues as a material. Furthermore, by fitting the data with a simple mechanical model for the cell wall, it is possible to extract information about the role moisture plays in the mechanics of the hemicellulose/lignin matrix. The data has furthermore potential for targeted design approaches for new passively moving materials which considers both swelling and shrinkage and changing mechanical properties to either amplify or weaken such movements.

\section{Materials and methods}

\section{Material}

To work with unmodified samples with a wide range of MFAs and to ensure a sufficient number of technical replicates, samples were taken from five different regions of Norway spruce trees (Picea abies L. [Karst.]) (Fig. 1): normal adult wood (AW) from the outermost growth rings of a mature tree; normal juvenile wood (JW) from the innermost growth rings of a young tree; stem compression wood (SCW1 and SCW2) from two different radial positions of a mature tree grown on a hill side; branch compression wood (BCW) from the lower part of a branch close to the stem. Samples were never dried and stored in a freezer at $-20{ }^{\circ} \mathrm{C}$. A bandsaw was used to cut small blocks from each wood type, which were then mounted on a rotary microtome (Zeiss RM2255), and selected growth rings were successively cut into longitudinal-tangential (TL) slices of $150 \mu \mathrm{m}$ for all wood types but the branch compression wood $(100 \mu \mathrm{m})$. A single slice containing "transition wood" from the zone between pure earlywood and latewood with comparably thick cell walls to avoid tension buckling effects during the tensile tests (Eder et al. 2008) was selected for further analysis. A small part of each slice was used to determine the mean MFA with wide angle X-ray diffraction (WAXD).

\section{Microfibril angle determination}

WAXD measurements were performed on dry samples (vacuum) on a Bruker AXS Nanostar equipped with a 2D Vantec 2000 area detector by Bruker Karlsruhe, Germany. The incident beam $(\sim 500 \mu \mathrm{m})$ hit the samples perpendicular to the fibre length axis and 2D diffraction patterns were collected by the detector at a sampleto-detector distance of $\sim 10 \mathrm{~cm}$ using $\mathrm{CuK} \alpha$ radiation (wavelength $\sim 0.154 \mathrm{~nm}$ ). The measuring time was $1 \mathrm{~h}$. The mean MFA was calculated following the method of Rüggeberg et al. (2013).

\section{Microtensile testing}

The major part of the TL-slices was kept wet and stored in the freezer at $-20{ }^{\circ} \mathrm{C}$. For the mechanical test, the slices were soaked in water and single fibres were 


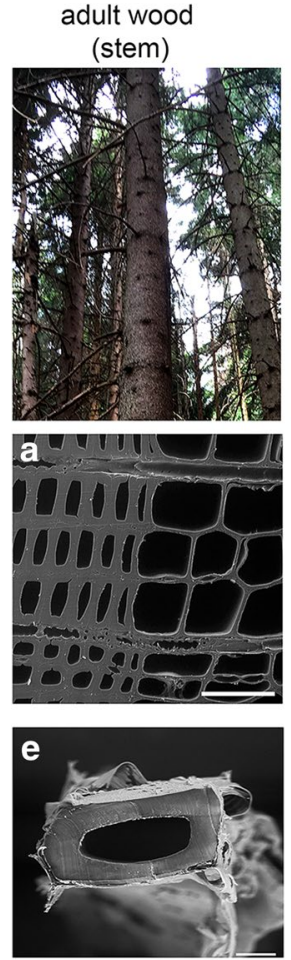

MFA $<10^{\circ}$
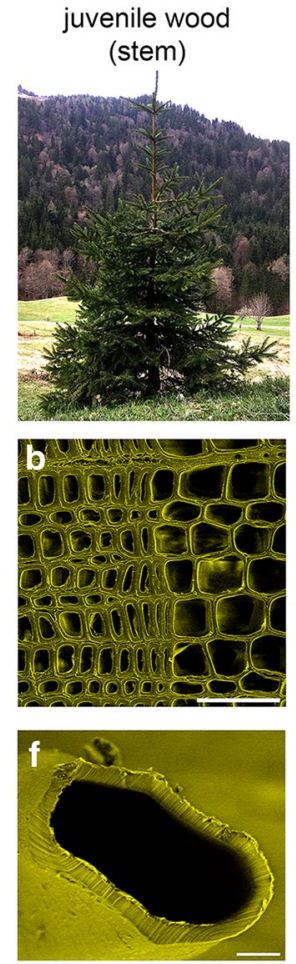

MFA $22^{\circ}$
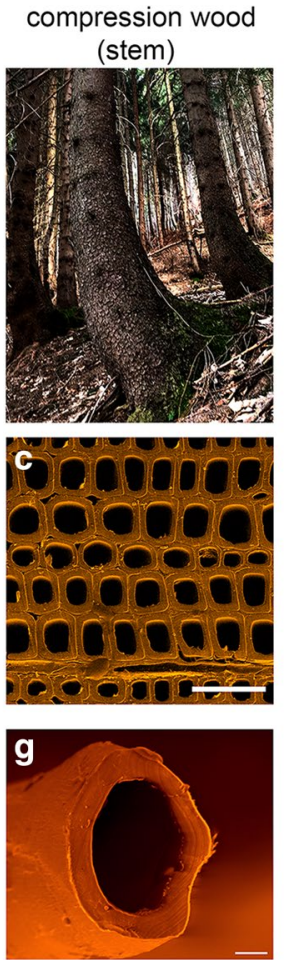

MFA $15^{\circ}$ and $26^{\circ}$ compression wood

(branch)
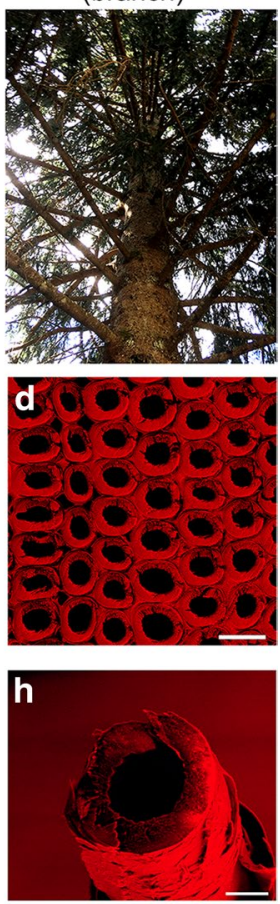

MFA $43^{\circ}$

Fig. 1 Spruce wood tissues from different regions of the tree-cellulose microfibril angles and cell structures. The first row shows photographs of an adult stem, stem of a juvenile tree, stem compression wood and spruce branches. The second row shows representative SEM images of cross sections of a adult wood (growth ring border), bar $50 \mu \mathrm{m}$, b juvenile wood (growth ring border), bar $50 \mu \mathrm{m}$, c stem compression wood (transition wood), bar $50 \mu \mathrm{m}$, d branch compression wood (transition wood), bar $20 \mu \mathrm{m}$. The third row shows SEM images of single fibres of $\mathbf{e}$ adult wood, bar $10 \mu \mathrm{m}$, $\mathbf{f}$ juvenile wood, bar $5 \mu \mathrm{m}$, g stem compression wood, bar $5 \mu \mathrm{m}$ and (h) branch compression wood, bar $5 \mu \mathrm{m}$. Values for the MFAs are given below the single-fibre micrographs

isolated mechanically by hand using very fine tweezers according to the method of Burgert et al. (2002). The isolated wet fibres were placed on a glass slide and dried at ambient conditions overnight under a cover glass to prevent twisting (Burgert et al. 2005b). In order to test fibres of each wood type conserved in the fully hydrated state, a set of fibres was stored in a mixture of water and glycerol $(1: 1)$ after isolation to prevent them from drying in later preparation steps. Single fibres were glued with cyanoacrylate super glue (Loctite 454) onto special foliar frames which allow for easy mounting in the tensile apparatus with a pinhole assembly and a strain detection using video extensometry (Burgert et al. 2003). Fibres with traces of glue along the test span were discarded. The free fibre length was determined by taking images with a light microscope (Leica DM RXA 2) equipped with a digital camera (Leica DFC 480) and subsequent image analysis with ImageJ. The free fibre 
length was $\sim 1.5 \mathrm{~mm}$ for $\mathrm{AW}, \mathrm{JW}$, and $\mathrm{SCW}$ and $\sim 0.7 \mathrm{~mm}$ for the $\mathrm{BCW}$ due to their naturally occurring shorter length.

Tensile tests were carried out with a custom built tensile apparatus with a measurement chamber which allowed for the control of the temperature and the relative humidity (RH) using an external thermostat (Huber Ministat $125 \mathrm{cc}$ ) and a humidity generator (Setaram Instrumentation Wetsys) with a heated transfer line to the measurement chamber to avoid condensation. The chamber temperature was kept constant at $30{ }^{\circ} \mathrm{C}$ to minimize the influence of temperature differences in the laboratory throughout all tensile experiments while the relative humidity was varied from 5 to 90\% RH. The temperature and relative humidity were measured inside the chamber with a combined sensor (Sensirion SHT75). After mounting the sample, the remaining supports of the foliar frame were cut with a thermocutting device. The chamber was closed and the sample and chamber were allowed to equilibrate at a chosen relative humidity for $\sim 20-40 \mathrm{~min}$ before starting the tensile test. The fully hydrated fibres were tested without closing the measurement chamber but under ambient conditions at $\sim 23{ }^{\circ} \mathrm{C}$. Here, a water vaporizer was used, which constantly blew water vapour onto the sample to keep it fully hydrated throughout the test.

Tensile forces were recorded with a load cell of $0.5 \mathrm{~N}$ maximum capacity. Testing speed was set to $2 \mu \mathrm{m} \mathrm{s}^{-1}$ for adult wood, juvenile wood and stem compression wood and reduced to $1 \mu \mathrm{m} \mathrm{s}^{-1}$ for branch compression wood to compensate for the shorter sample length. To calculate the stress, the cell wall cross-section area of the individual fibres (examples are shown in Fig. 1e-h) was determined with a FEI FEG-ESEM Quanta 600 in the low vacuum mode and subsequent image analysis (0.75 Torr) (Burgert et al. 2005a). Since the samples were not cooled they were imaged in the dry condition.

\section{Results and discussion}

WAXD analysis showed MFAs (the means of the Gaussian distribution) to be $\leq 10^{\circ}$ for adult wood, $15^{\circ}$ for stem compression wood $\# 1,22^{\circ}$ for juvenile wood; $26^{\circ}$ for stem compression wood \#2 (SCW2) and $43^{\circ}$ for branch compression wood. For each tissue, four sets of fibres were tested at different levels of relative humidity (RH) ranging from 5 to $90 \%$ and one set of fibres was tested under wet conditions. The equilibrium moisture contents under these environmental conditions were estimated to range from $\sim 1.5$ to $30 \%$, based on a Keylwerth diagram (Keylwerth and Noack 1964) and the fibre saturation point of spruce wood (Berry and Roderick 2005). However, one needs to keep in mind that the moisture content of compression wood fibres might differ by 5-20\% compared to the moisture content of normal wood (Rosenthal 2009). It must be kept in mind that the literature data was generated on bulk wood samples comprising the middle lamellae. There is a possibility that equilibrium moisture contents of single fibres are slightly different compared to wood samples.

Stress-strain curves of the tested single fibres were calculated from the experimental force displacement curves and the dry cell wall cross sections. This means that the calculated tensile stiffness and strength in the hydrated condition were slightly 
overestimated since cell wall swelling was not considered. Despite this, as the stiffnesses and strengths are related to the dry cross-section, they still can take into account differences in the amount of cell wall material that carries load between samples. The series of juvenile wood tested under wet conditions is missing due to the exhaustion of the used wood slice. The plotted mean tensile stiffness of the fully hydrated fibres (Fig. 2) clearly shows, in accordance with previous publications (Cave 1969; Groom et al. 2002a; Mott et al. 2002; Page and Elhosseiny 1983; Reiterer et al. 1999), that stiffness decreases drastically with increasing MFA by approximately one order of
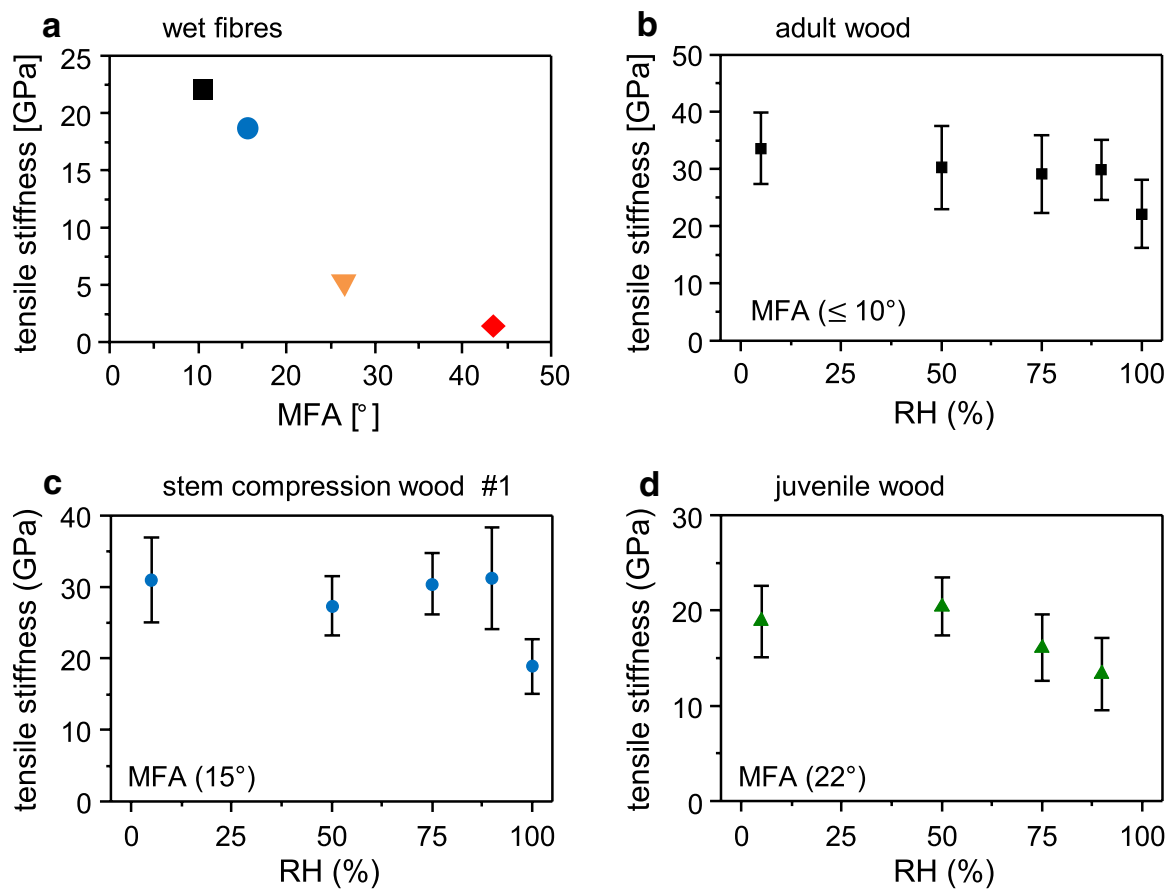

e stem compression wood \#2
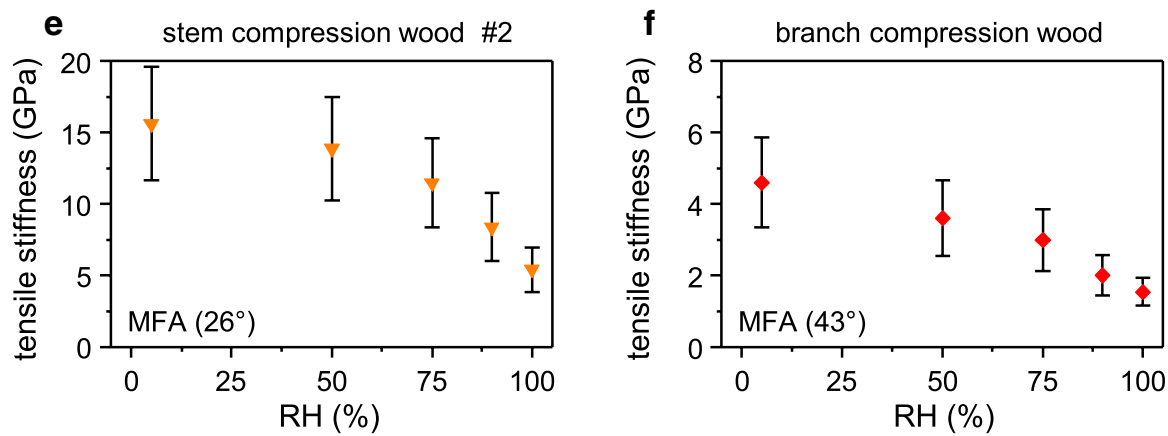

Fig. 2 Tensile stiffness of single wood fibres with different microfibril angles. a tensile stiffness plotted versus the microfibril angle (MFA) of fully wet fibres. b-f tensile stiffness versus relative humidity for different microfibril angles, data points are the arithmetic means of $\sim 10$ fibres each, error bars show standard deviation (see Table 1 for more details) 
magnitude from adult wood fibres with a MFA $<10^{\circ}$ to branch compression wood with a MFA $>40^{\circ}$. This can be explained by the increasing proportion of load taken up by the soft matrix in shear with increasing microfibril angle. In fibres with small MFAs, the load is taken up mainly by the stiff cellulose fibrils, but in large MFAs the matrix is put under shear and will deform giving rise to a reduced fibre stiffness. For the tensile tests performed under different RHs, the tensile stiffness decreases with increasing moisture content in all tissues (Fig. 2). It is particularly interesting that for tissues with small MFAs, a clear decrease in tensile stiffness can only be observed for the fully hydrated fibres.

The decrease in stiffness from the dry to the fully hydrated state was $\sim 34 \%$ for adult wood and for stem compression wood \#1 a decrease of $39 \%$ was observed which is less than the observed decrease of $\sim 44 \%$ found by Kersevage (1973) for chemically isolated single fibres from Douglas fir with a typically low MFA. The stiffness decrease observed between our wet and dry Norway spruce fibres is similar to what has been reported for dry ( $40 \% \mathrm{RH}$ at room temperature) and wet bulk Norway spruce wood with similar MFAs (Almeras et al. 2017). This finding supports that stiffness decrease upon moisture uptake of bulk wood when loaded along the fibre axis is mainly controlled by the fibre cell wall and that the compound middle lamellae plays only a minor role in the mechanical response of bulk material under tension. In the case of the fibres with higher MFAs, the decrease in tensile stiffness is observed at lower equilibrium moisture contents. It is assumed this is a consequence of the higher shear stresses acting on the hemicellulose-lignin matrix between the stiff cellulose fibrils. Furthermore, the stiffness reduction is much more pronounced for fibres with high cellulose angles $\left(\sim 34 \%\right.$ for a MFA of $\sim 10^{\circ}$ vs. $\sim 68 \%$ for $\left.\sim 43^{\circ}\right)$. Wang et al. (2017) showed on wood slices of Masson pine that the moisture-induced decrease in tensile stiffness (5-8\% equilibrium moisture content vs. fully hydrated) becomes more pronounced with increasing MFA. However, the values cannot be compared directly since the measurements were performed on tissue slices.

Since several native wood fibres with different MFAs were tested at five different moisture conditions $(5,50,75,90 \% \mathrm{RH}$ and fully hydrated) with estimated moisture contents of 1.5, 9, 14, 20 and 29\%, (the estimations are based on a Keylwerth diagram (Keylwerth and Noack 1964)), the dataset can be fitted to the following relationship:

$$
E_{\text {Effective }}=E_{\text {matrix }} \frac{1+f\left(1-2(1+v) m^{2} n^{2}\right) /\left(1-v^{2}\right)}{1+n^{4} f}
$$

Table 1 Matrix modulus as a function of relative humidity (or moisture content) calculated from the fits of Eq. (1) to the experimental data (Table 2)

\begin{tabular}{lll}
\hline $\mathrm{RH}[\%]$ & MC [\%] & Ematrix [GPa] \\
\hline 5 & 1.5 & 3.702 \\
50 & 9 & 2.602 \\
75 & 14 & 2.054 \\
90 & 20 & 1.326 \\
Wet & 29 & 0.330 \\
\hline
\end{tabular}


where the matrix modulus $E_{\text {matrix }}$ and f depend on hydration state only and $m=\cos \mu$, $n=\sin \mu$, where $\mu$ is the microfibril angle. For simplicity, we assume that $\mu$ remains constant with changing moisture content. $f$ is given by $f=k / E_{\text {matrix }}$, where k is a constant that describes the relative load bearing capacity of the cellulose fibrils with respect to the matrix. $k$ describes not only the relative stiffness of the cellulose microfibrils but also their relative amounts with respect to the matrix (i.e. a small number of very stiff fibrils will have a small influence on the effective tissue stiffness). The model does not take into account any changes in cell wall thickness due to hydration, and assumes all changes in the effective modulus with hydration are due to variations in $E_{\text {matrix }}$ and $k$ alone. An advantage of this is it allow the equation to be directly compared to the experimental data where stresses are calculated from the dry cell wall cross section. For a detailed derivation of this equation see Fratzl et al. (2008). This function was fitted to the experimental data using a nonlinear model fitting procedure in Mathematica (12.1 Wolfram Research) using a Poisson ratio of $(v=0.3)$ and $k=27 \mathrm{GPa}$ (Fig. 3a-e). The fitting procedure gives the matrix modulus for different relative humidities (moisture contents) (see Table 2 and Fig. 3f). The matrix modulus decreases with hydration by a factor of $\sim 10$ from 3.70 to $0.33 \mathrm{GPa}$. When plotted against moisture content, the matrix modulus can be fitted with the following equation:

$$
E_{\text {matrix }}=(3.788 \pm 0.238)-\mathrm{mc}(0.121 \pm 0.014) \mathrm{GPa},
$$

where $\mathrm{mc}=$ moisture content and the errors indicate the $95 \%$ confidence interval.

The experimental data fit Eq. (1) well except for some data points at low MFAs and high moisture contents (Fig. 3d and e). The samples tested at 75 and $90 \%$ RH with a $15^{\circ}$ MFA show higher stiffnesses than the samples with an $8^{\circ}$ MFA. Most likely this is due to a natural variation of the tested samples as to the best of the authors knowledge no comparable literature data exists that indicates a moisture related effect for these low fibre angles. It is also possible that the mass ratio of cellulose to matrix is different for the different tissues (especially for compression wood), giving a tissue dependent fitting parameter $k$. As we have no data on how $k$ varies as a function of the mass ratio of cellulose to matrix, nor any experimental data to test this, the $k$ was chosen, which gave the best fit over the entire data set giving a maximum of the sum of the $R^{2}$ of the individual fits. The situation for the data point of adult wood in the fully hydrated state is different. Such drastic stiffness decreases in the fully hydrated state of wood with a low MFA have also been observed by other researchers on tissue slices, bulk wood samples and also on single fibres and it is certainly a material response to moisture (Eder et al. 2013; Kersevage 1973; Kollmann 1951; Wang et al. 2017). However, most of the literature data is only available for "dry" and "fully hydrated" samples, except for studies on clear wood samples where it has been shown that modulus of elasticity gradually decreases with moisture content (Kollmann 1951; Niemz and Sonderegger 2017). Unfortunately, for the majority of data, information about the MFA is not available.

The data and the fitted model can be re-plotted as a function of moisture content (Fig. 4 b). It is interesting to observe on single fibres with a MFA of $15^{\circ}$ or smaller that tensile stiffness does not decrease much upon hydration unless the 

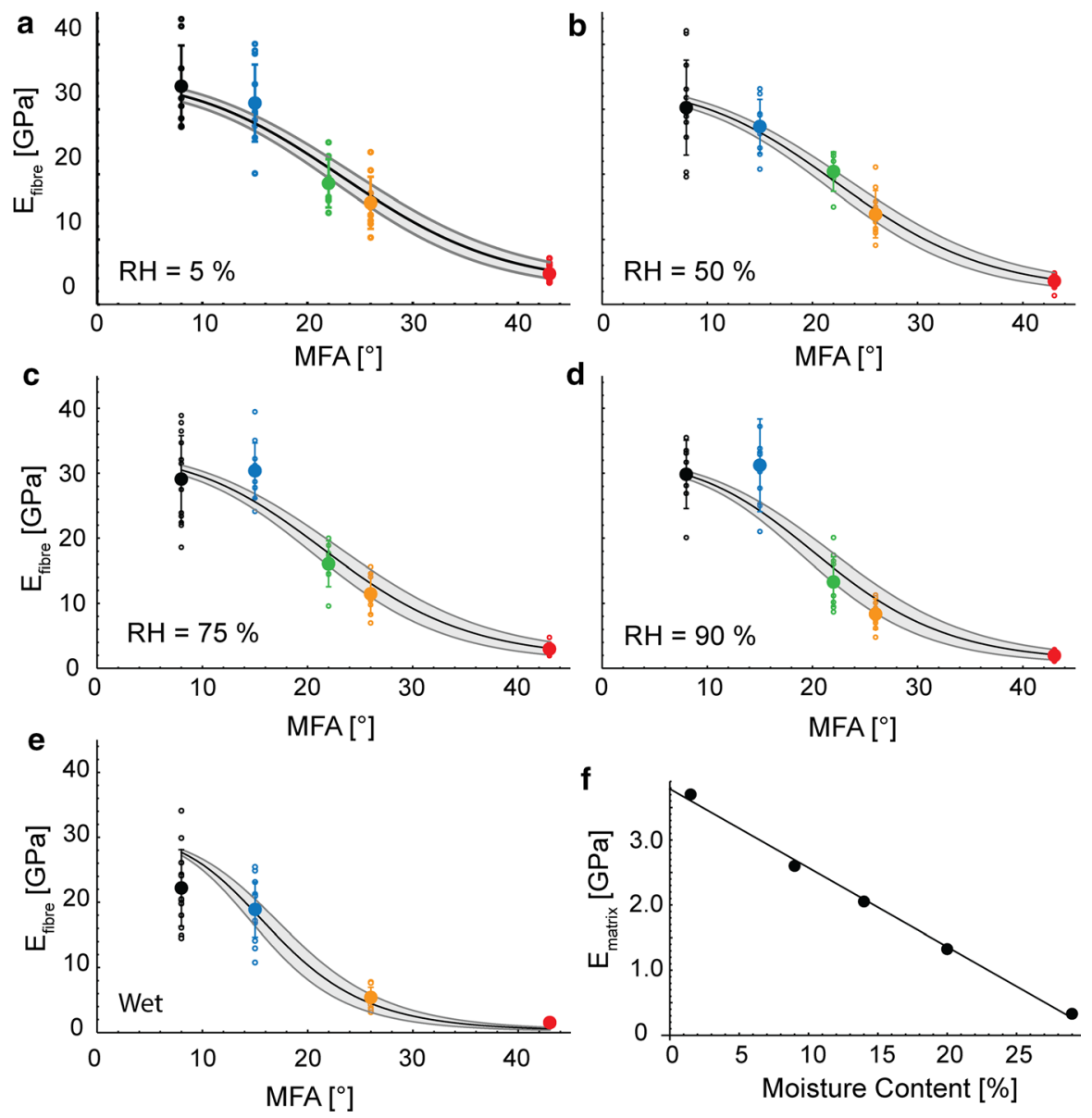

Fig. 3 Tensile stiffness versus MFA for different relative humidities. a-e Plots of experimental and calculated fibre stiffness as a function of microfibril angle The large circles indicate the mean experimental values, the smaller circles show the individual data points, and error bars show the standard deviation (see Table 1 for more details). The fitted curves based on Eq. (1) are shown in black with the grey regions highlighting the $95 \%$ confidence interval of the fits. f Plot of the fitted matrix modulus values as a function of moisture content together with a linear fit

material is fully hydrated. The data for small MFAs cannot be fitted well with the current model at high moisture contents, but the model does verify that the absolute change in matrix stiffness is stronger for microfibril angles of $15-26^{\circ}$. The model in Fratzl et al. (2008) is used to calculate the relative amount of tensile stress that is transferred to the fibrils as a function of microfibril angle (Fig. 4c). The stress taken up by the fibrils divided by the tensile load shows a peak for microfibril angles around $33^{\circ}$. This suggests that higher fibril stresses occur at microfibril angles of $25-40^{\circ}$, which in turn would require a more effective stress transfer to the matrix. Although the stiffness changes at high $\left(43^{\circ}\right)$ 
Table 2 Cellulose fibril angle, MFA and tensile properties of single wood cells

\begin{tabular}{|c|c|c|c|c|c|c|c|c|c|}
\hline \multirow{2}{*}{$\begin{array}{l}\text { Wood type } \\
\text { Adult wood }\end{array}$} & \multirow{2}{*}{$\begin{array}{l}\operatorname{MFA}\left[{ }^{\circ}\right] \\
8\end{array}$} & \multirow{2}{*}{$\begin{array}{l}\mathrm{RH}[\%] \\
5\end{array}$} & \multirow{2}{*}{$\begin{array}{c}n \\
\\
\\
\\
9\end{array}$} & \multicolumn{2}{|c|}{$\begin{array}{l}\text { Tensile stiff- } \\
\text { ness [GPa] }\end{array}$} & \multicolumn{2}{|c|}{$\begin{array}{l}\text { Ultimate stress } \\
{[\mathrm{MPa}]}\end{array}$} & \multicolumn{2}{|c|}{$\begin{array}{l}\text { Cell wall } \\
\text { cross- } \\
\text { section area } \\
{\left[\mu \mathrm{m}^{2}\right]}\end{array}$} \\
\hline & & & & 33.6 & $( \pm 6.3)$ & 844 & $( \pm 227)$ & 503 & $( \pm 121)$ \\
\hline & 8 & 50 & 12 & 30.3 & $( \pm 7.9)$ & 982 & $( \pm 250)$ & 414 & $( \pm 132)$ \\
\hline & 8 & 75 & 13 & 29.1 & $( \pm 6.7)$ & 939 & $( \pm 235)$ & 479 & $( \pm 121)$ \\
\hline & 8 & 90 & 7 & 29.8 & $( \pm 5.3)$ & 968 & $( \pm 296)$ & 415 & $( \pm 103)$ \\
\hline & 8 & Wet & 13 & 22.2 & $( \pm 5.9)$ & 646 & $( \pm 266)$ & 414 & $( \pm 84)$ \\
\hline \multirow[t]{5}{*}{ Stem compression wood } & 15 & 5 & 12 & 31.0 & $( \pm 5.9)$ & 911 & $( \pm 255)$ & 261 & $( \pm 68)$ \\
\hline & 15 & 50 & 9 & 26.6 & $( \pm 4.7)$ & 927 & $( \pm 390)$ & 257 & $( \pm 49)$ \\
\hline & 15 & 75 & 11 & 30.4 & $( \pm 4.3)$ & 1065 & $( \pm 333)$ & 232 & $( \pm 51)$ \\
\hline & 15 & 90 & 10 & 31.2 & $( \pm 7.1)$ & 808 & $( \pm 229)$ & 203 & $( \pm 42)$ \\
\hline & 15 & Wet & 15 & 18.9 & $( \pm 3.8)$ & 729 & $( \pm 163)$ & 260 & $( \pm 56)$ \\
\hline \multirow[t]{5}{*}{ Juvenile wood } & 22 & 5 & 8 & 18.9 & $( \pm 3.8)$ & 644 & $( \pm 211)$ & 135 & $( \pm 35)$ \\
\hline & 22 & 50 & 6 & 20.5 & $( \pm 3.4)$ & 827 & $( \pm 307)$ & 126 & $( \pm 29)$ \\
\hline & 22 & 75 & 7 & 16.1 & $( \pm 3.5)$ & 764 & $( \pm 251)$ & 136 & $( \pm 30)$ \\
\hline & 22 & 90 & 11 & 13.3 & $( \pm 3.8)$ & 712 & $( \pm 213)$ & 135 & $( \pm 38)$ \\
\hline & 22 & Wet & NA & NA & & NA & & NA & \\
\hline \multirow[t]{5}{*}{ Stem compression wood } & 26 & 5 & 10 & 15.6 & $( \pm 4.0)$ & 356 & $( \pm 106)$ & 298 & $( \pm 68)$ \\
\hline & 26 & 50 & 11 & 13.9 & $( \pm 3.6)$ & 498 & $( \pm 111)$ & 313 & $( \pm 69)$ \\
\hline & 26 & 75 & 9 & 11.0 & $( \pm 3.2)$ & 412 & $( \pm 86)$ & 351 & $( \pm 121)$ \\
\hline & 26 & 90 & 8 & 8.4 & $( \pm 2.4)$ & 341 & $( \pm 97)$ & 321 & $( \pm 106)$ \\
\hline & 26 & Wet & 12 & 5.4 & $( \pm 1.6)$ & 267 & $( \pm 104)$ & 302 & $( \pm 54)$ \\
\hline \multirow[t]{5}{*}{ Branch compression wood } & 43 & 5 & 11 & 4.7 & $( \pm 1.3)$ & 137 & $( \pm 30)$ & 186 & $( \pm 34)$ \\
\hline & 43 & 50 & 12 & 3.6 & $( \pm 1.0)$ & 147 & $( \pm 44)$ & 204 & $( \pm 25)$ \\
\hline & 43 & 75 & 11 & 3.2 & $( \pm 0.9)$ & 163 & $( \pm 69)$ & 174 & $( \pm 28)$ \\
\hline & 43 & 90 & 11 & 2.0 & $( \pm 0.6)$ & 150 & $( \pm 50)$ & 209 & $( \pm 50)$ \\
\hline & 43 & Wet & 11 & 1.5 & $( \pm 0.4)$ & 186 & $( \pm 43)$ & 172 & $( \pm 31)$ \\
\hline
\end{tabular}

Values in parentheses are the standard deviations

and intermediate MFAs (22 and $26^{\circ}$ ) are similar, the fibrillar stress should be much lower at high MFAs $\left(>40^{\circ}\right)$. This would imply a smaller amount of stress is transferred to the matrix from the fibrils meaning a lower sensitivity to changes in hydration.

Finally, the experimental observations of a strong decrease in stiffness upon complete hydration at low MFAs lead to the following speculations:

- The cellulose stiffness itself may change when it becomes completely hydrated (Kulasinski et al. 2017), perhaps due to the presence of amorphous regions. This is supported by molecular dynamics simulations performed by Kulasinski et al. (2017). 

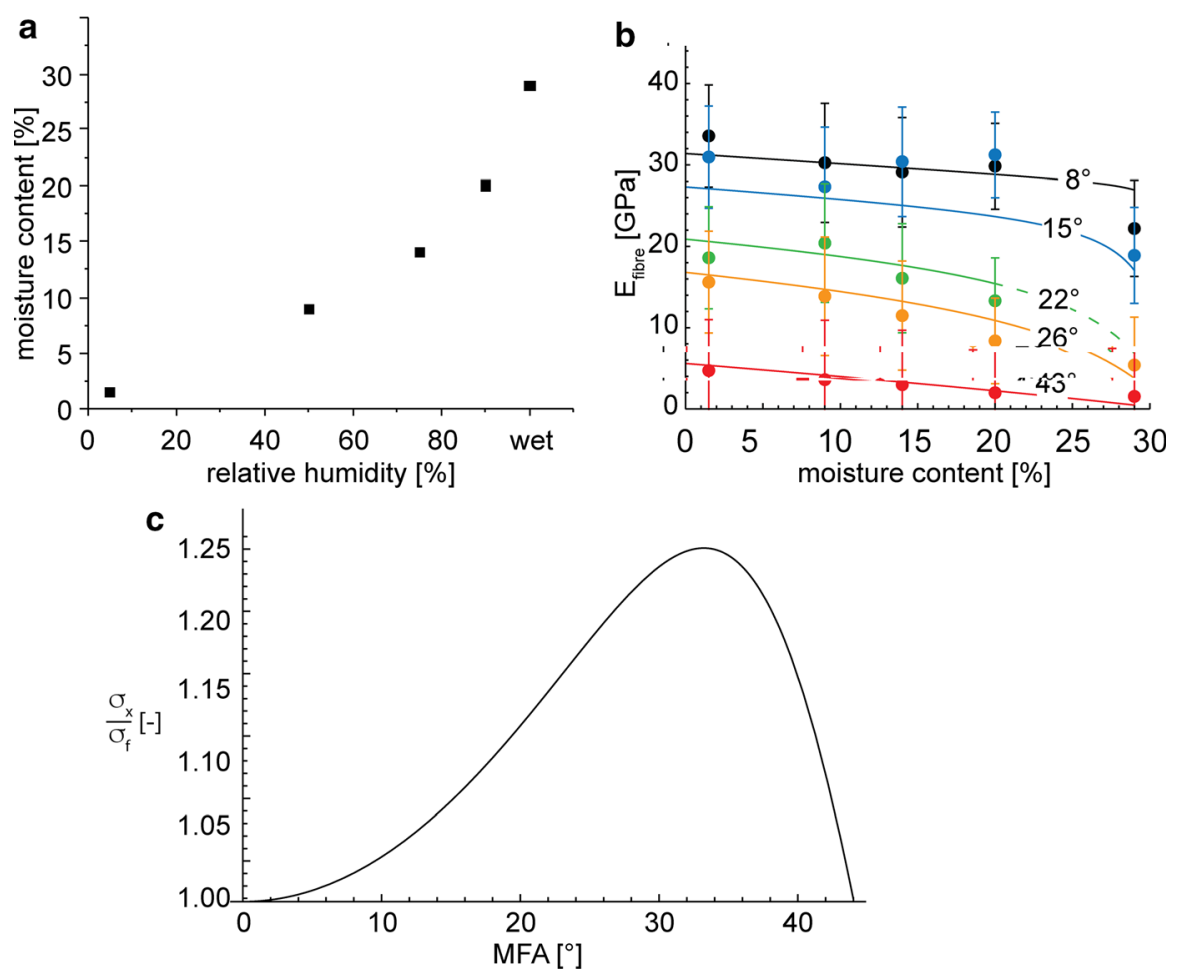

Fig. 4 a Equilibrium moisture content of the tested single fibres. The values were estimated based on a Keylwerth diagram (5-90\% r. h.) (Keylwerth and Noack 1964) and on the fibre saturation point for wood (wet) b Tensile stiffness versus moisture content for different microfibril angles. The circles indicate experimental data with error bars indicating standard deviation and solid lines giving the fitted model (Eq. (1)). The dotted $\left(22^{\circ}\right)$ green line indicates the prediction of the model for high moisture contents for the juvenile wood $\mathbf{c}$ Relative increase in the fibril tensile stress with respect to fibre stress as a function of microfibril angle. Calculated using the model from Fratzl et al. (2008)

- The interfacial bonding between cellulose fibrils and matrix may change upon hydration. The simulations of Kulasinski et al. (2017) also suggest that the cellulose-hemicellulose interface may adsorb up to $1 / 3$ of the total moisture, which again may change the stress transfer between the phases.

- That hydration and therefore swelling of the matrix deforms the cellulose crystals (Zabler et al. 2010). X-ray measurements have shown that changes in hydration indeed deform crystals, which may in turn change their interaction with matrix or even their mechanical properties. 


\section{Conclusion}

This paper presents an extensive set of tensile data coming from single wood fibres with different microfibril angles tested at different moisture contents. The data set was fitted with a simple theoretical model based on fibre composite mechanics allowing information about the change in matrix stiffness with changing hydration. Although the interpretation of some of the data especially for microfibril angles of 22 and $26^{\circ}$ is complex, the data provide a good baseline for future work into the role of moisture on the mechanics of wood and other plant tissues.

Acknowledgements NH, LB, PF and ME acknowledge the support of the Max Planck Society, JWCD thanks the University of Salzburg.

Author's contributions ME conceptualized the study, NH, LB and ME designed the mechanical testing setup, $\mathrm{NH}$ performed experiments including data analysis, PF and JWCD developed code and model. NH and ME wrote the first draft of the manuscript. All authors discussed, commented, wrote text passages and approved the manuscript.

Funding Open Access funding enabled and organized by Projekt DEAL.

Data availability Data and code are available from the corresponding author on request.

\section{Declarations}

Conflict of interests We have no competing interests.

Open Access This article is licensed under a Creative Commons Attribution 4.0 International License, which permits use, sharing, adaptation, distribution and reproduction in any medium or format, as long as you give appropriate credit to the original author(s) and the source, provide a link to the Creative Commons licence, and indicate if changes were made. The images or other third party material in this article are included in the article's Creative Commons licence, unless indicated otherwise in a credit line to the material. If material is not included in the article's Creative Commons licence and your intended use is not permitted by statutory regulation or exceeds the permitted use, you will need to obtain permission directly from the copyright holder. To view a copy of this licence, visit http://creativecommons.org/licen ses/by/4.0\%.

\section{References}

Almeras T, Gronvold A, van der Lee A, Clair B, Montero C (2017) Contribution of cellulose to the moisture-dependent elastic behaviour of wood. Compos Sci Technol 138:151-160. https://doi. org/10.1016/j.compscitech.2016.11.025

Barnett JR, Bonham VA (2004) Cellulose microfibril angle in the cell wall of wood fibres. Biol Rev 79:461-472. https://doi.org/10.1017/S1464793103006377

Berry SL, Roderick ML (2005) Plant-water relations and the fibre saturation point. New Phytol 168:25-37. https://doi.org/10.1111/j.1469-8137.2005.01528.x

Burgert I, Keckes J, Frühmann K, Fratzl P, Tschegg SE (2002) A comparison of two techniques for wood fibre isolation evaluation by tensile tests on single fibres with different microfibril angle. Plant Biol 4:9-12. https://doi.org/10.1055/s-2002-20430

Burgert I, Frühmann K, Keckes J, Fratzl P, Stanzl-Tschegg SE (2003) Microtensile testing of wood fibers combined with video extensometry for efficient strain detection. Holzforschung 57:661664. https://doi.org/10.1515/HF.2003.099 
Burgert I, Eder M, Frühmann K, Keckes J, Fratzl P, Stanzl-Tschegg S (2005a) Properties of chemically and mechanically isolated fibres of spruce (Picea abies [L.] Karst.). Part 3: mechanical characterisation. Holzforschung 59:354-357. https://doi.org/10.1515/HF.2005.058

Burgert I, Gierlinger N, Zimmermann T (2005b) Properties of chemically and mechanically isolated fibres of spruce (Picea abies [L.] Karst.). Part 1: structural and chemical characterisation. Holzforschung 59:240-246. https://doi.org/10.1515/HF.2005.038

Cave ID (1969) Longitudinal Youngs Modulus of pinus radiata. Wood Sci Technol 3:40-48. https:// doi.org/10.1007/Bf00349983

Eder M, Stanzl-Tschegg S, Burgert I (2008) The fracture behaviour of single wood fibres is governed by geometrical constraints: in situ ESEM studies on three fibre types. Wood Sci Technol 42:679689. https://doi.org/10.1007/s00226-008-0214-5

Eder M, Arnould O, Dunlop JWC, Hornatowska J, Salmen L (2013) Experimental micromechanical characterisation of wood cell walls. Wood Sci Technol 47:163-182. https://doi.org/10.1007/ s00226-012-0515-6

Fratzl P, Elbaum R, Burgert I (2008) Cellulose fibrils direct plant organ movements. Faraday Discuss 139:275-282. https://doi.org/10.1039/b716663j

Gindl W, Schoberl T (2004) The significance of the elastic modulus of wood cell walls obtained from nanoindentation measurements. Compos Part A Appl Sci 35:1345-1349. https://doi.org/10. 1016/j.compositesa.2004.04.002

Gindl W, Gupta HS, Schoberl T, Lichtenegger HC, Fratzl P (2004) Mechanical properties of spruce wood cell walls by nanoindentation. Appl Phys A 79:2069-2073. https://doi.org/10.1007/ s00339-004-2864-y

Groom L, Mott L, Shaler S (2002a) Mechanical properties of individual southern pine fibers. Part I. Determination and variability of stress-strain curves with respect to tree height and juvenility. Wood Fiber Sci 34:14-27

Groom L, Shaler S, Mott L (2002b) Mechanical properties of individual southern pine fibers. Part III: global relationships between fiber properties and fiber location within an individual tree. Wood Fiber Sci 34:238-250

Jäger A, Bader T, Hofstetter K, Eberhardsteiner J (2011) The relation between indentation modulus, microfibril angle, and elastic properties of wood cell walls. Compos Part A Appl Sci Manuf 42:677-685. https://doi.org/10.1016/j.compositesa.2011.02.007

Joffre T, Neagu RC, Bardage SL, Gamstedt EK (2014) Modelling of the hygroelastic behaviour of normal and compression wood tracheids. J Struct Biol 185:89-98. https://doi.org/10.1016/j.jsb. 2013.10.014

Keckes J, Burgert I, Frühmann K et al (2003) Cell-wall recovery after irreversible deformation of wood. Nat Mater 2:810-814. https://doi.org/10.1038/nmat1019

Kersevage PC (1973) Moisture content effect on tensile properties of individual Douglas-fir latewood tracheids. Wood Fiber Sci 5:105-117

Keylwerth R, Noack D (1964) Die Kammertrocknung von Schnittholz. (Chamber drying of sawn timber) (In German) Holz Roh- Werkst 22:29-36

Kollmann F (1951) Technologie des Holzes und der Holzwerkstoffe: 1. Band (Technology of wood and wood-based products: Vol. 1). Springer, Berlin, Heidelberg

Kulasinski K, Derome D, Carmeliet J (2017) Impact of hydration on the micromechanical properties of the polymer composite structure of wood investigated with atomistic simulations. J Mech Phys Solids 103:221-235. https://doi.org/10.1016/j.jmps.2017.03.016

Mott L, Groom L, Shaler S (2002) Mechanical properties of individual southern pine fibers. Part II. Comparison of earlywood and latewood fibers with respect to tree height and juvenility. Wood Fiber Sci 34:221-237

Niemz P, Sonderegger W (2017) Holzphysik. Carl Hanser Verlag, München, Physik des Holzes und der Holzwerkstoffe

Page DH, Elhosseiny F (1983) The mechanical-properties of single wood pulp fibers. 6. Fibril angle and the shape of the stress-strain curve. Pulp P Can 84:Tr99-T100

Pan YH, Zhong Z (2016) Micromechanical modeling of the wood cell wall considering moisture absorption. Compos Part B Eng 91:27-35. https://doi.org/10.1016/j.compositesb.2015.12.038

Reiterer A, Lichtenegger H, Tschegg S, Fratzl P (1999) Experimental evidence for a mechanical function of the cellulose microfibril angle in wood cell walls. Philos Mag A 79:2173-2184. https:// doi.org/10.1080/01418619908210415 
Reyssat E, Mahadevan L (2009) Hygromorphs: from pine cones to biomimetic bilayers. J R Soc Interface 6:951-957. https://doi.org/10.1098/rsif.2009.0184

Rosenthal M (2009) Entwicklung eines biologisch inspirierten, dreidimensional verformbaren Furniers aus Druckholz. ( Development of a biologically inspired, three-dimensionally deformable veneer made of compression wood) (In German). Doctoral Thesis, TU Dresden

Rüggeberg M, Burgert I (2015) Bio-inspired wooden actuators for large scale applications. PLoS ONE. https://doi.org/10.1371/journal.pone.0120718

Rüggeberg M, Saxe F, Metzger TH, Sundberg B, Fratzl P, Burgert I (2013) Enhanced cellulose orientation analysis in complex model plant tissues. J Struct Biol 183:419-428. https://doi.org/10. 1016/j.jsb.2013.07.001

Salmen L (2004) Micromechanical understanding of the cell-wall structure. Cr Biol 327:873-880. https://doi.org/10.1016/j.crvi.2004.03.010

Tze WTY, Wang S, Rials TG, Pharr GM, Kelley SS (2007) Nanoindentation of wood cell walls: continuous stiffness and hardness measurements. Compos Part A Appl Sci Manuf 38:945-953. https://doi.org/10.1016/j.compositesa.2006.06.018

Vailati C, Hass P, Burgert I, Rüggeberg M (2017) Upscaling of wood bilayers: design principles for controlling shape change and increasing moisture change rate. Mater Struct. https://doi.org/10. $1617 / \mathrm{s} 11527-017-1117-4$

Wang HK, Yu ZX, Zhang XX, Ren D, Yu Y (2017) The combined effects of initial microfibrillar angle and moisture contents on the tensile mechanical properties and angle alteration of wood foils during tension. Holzforschung 71:491-497. https://doi.org/10.1515/hf-2016-0138

Zabler S, Paris O, Burgert I, Fratzl P (2010) Moisture changes in the plant cell wall force cellulose crystallites to deform. J Struct Biol 171:133-141. https://doi.org/10.1016/j.jsb.2010.04.013

Zhang LD, Chizhik S, Wen YZ, Naumov P (2016) Directed motility of hygroresponsive biomimetic actuators. Adv Funct Mater 26:1040-1053. https://doi.org/10.1002/adfm.201503922

Publisher's Note Springer Nature remains neutral with regard to jurisdictional claims in published maps and institutional affiliations. 